Article

\title{
Hydrological Extremes in the Canadian Prairies in the Last Decade due to the ENSO Teleconnection-A Comparative Case Study Using WRF
}

\author{
Soumik Basu *(1), David J. Sauchyn and Muhammad Rehan Anis \\ Prairie Adaptation Research Collaborative, Regina, SK S4S 0A2, Canada; sauchyn@uregina.ca (D.J.S.); \\ rehananis@uregina.ca (M.R.A.) \\ * Correspondence: Soumik.Basu@uregina.ca
}

Received: 8 September 2020; Accepted: 21 October 2020; Published: 23 October 2020

\begin{abstract}
In the Prairie provinces of Alberta, Saskatchewan, and Manitoba, agricultural production depends on winter and spring precipitation. There is large interannual variability related to the teleconnection between the regional hydroclimate and El Niño and La Niña in the Tropical Pacific. A modeling experiment was conducted to simulate climatic and hydrological parameters in the Canadian Prairie region during strong El Niño and La Niña events of the last decade in 2015-2016 and 2010-2011, respectively. The National Center for Atmospheric Research (NCAR) Weather Research and Forecasting (WRF) model was employed to perform two sets of sensitivity experiments with a nested domain at $10 \mathrm{~km}$ resolution using the European Centre for Medium-Range Weather Forecasts Reanalysis (ERA) interim data as the lateral boundary forcing. Analysis of the hourly model output provides a detailed simulation of the drier winter, with less soil moisture in the following spring, during the 2015-2016 El Niño and a wet winter during the La Niña of 2010-2011. The high-resolution WRF simulation of these recent weather events agrees well with observations from weather stations and water gauges. Therefore, we were able to take advantage of the WRF model to simulate recent weather with high spatial and temporal resolution and thus study the changes in hydrometeorological parameters across the Prairie during the two extreme hydrological events of the last decade.
\end{abstract}

Keywords: Canadian Prairie climate; ENSO; downscaling; WRF

\section{Introduction}

The Canadian Prairie provinces of Alberta, Saskatchewan, and Manitoba are known for their extreme seasonal climate and large interannual variability of hydrometeorological parameters [1,2]. Precipitation exhibits the largest spatial and temporal variability [3,4]. The major drivers of the interannual variability are the teleconnections with various large-scale climate patterns, especially El Niño Southern Oscillation (ENSO) [5-8]. Sea surface temperature (SST) anomalies in the tropical Pacific during the two phases of ENSO (El Niño/La Niña) affect North American mid-latitude weather through modulation of atmospheric circulation.

The Oceanic Niño Index (ONI) is an index of SST anomalies in the tropical Pacific commonly used to estimate the intensity of the phases of ENSO. The ONI is calculated by averaging sea surface temperature anomalies in an area of the east-central equatorial Pacific Ocean $\left(5^{\circ} \mathrm{S}\right.$ to $5^{\circ} \mathrm{N} ; 170^{\circ} \mathrm{W}$ to $120^{\circ} \mathrm{W}$ ). A 3-month time average (running mean) is calculated to better isolate variability closely related to the ENSO. An ONI of +0.5 or higher indicates El Niño conditions when the east-central tropical Pacific is significantly warmer than normal. An ONI of -0.5 or lower corresponds to La Niña conditions when SSTs in the region are cooler than usual. The last decade has experienced one of 
the strongest El Niño events of the century in 2015-2016 and a strong La Niña event in 2010-2011 (Figure 1). An El Niño (La Niña) year is characterized by warmer (colder) SSTs in the tropical Pacific with associated changes in oceanic and atmospheric circulation [9-12]. Ref. [13] demonstrated how mid-tropospheric circulation characterized by ridging and troughing is associated with dry/cold and wet weather, respectively, in the Canadian Prairies.

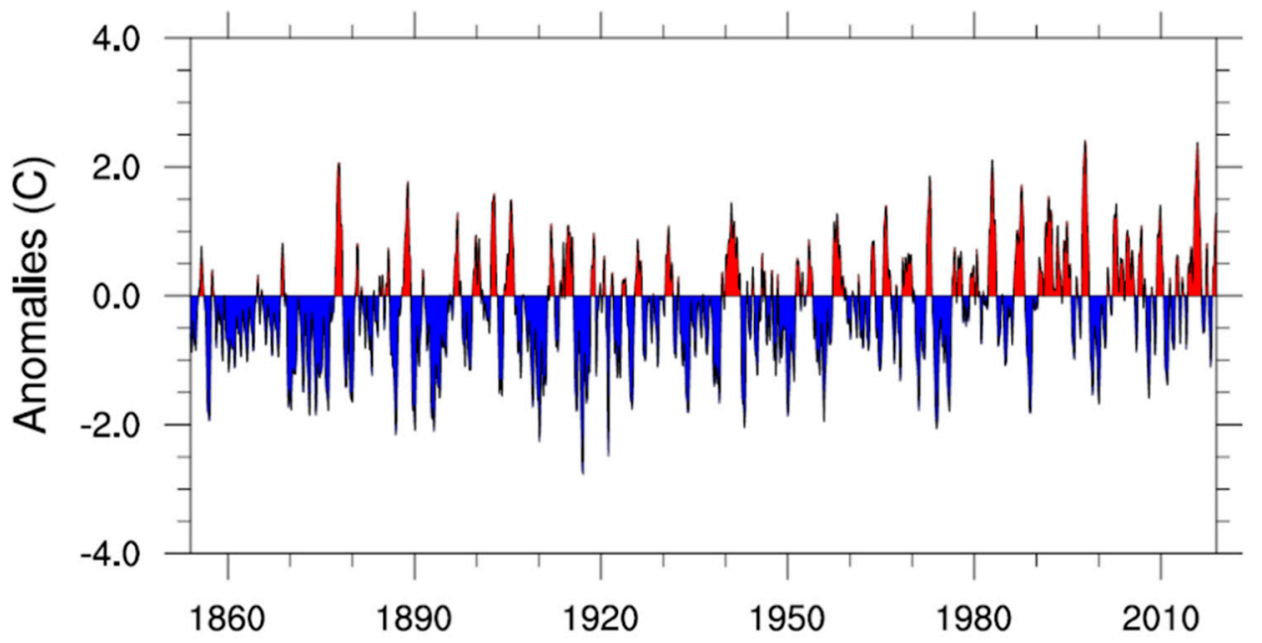

Figure 1. Oceanic Niño Index (ONI) calculated from NOAA Extended Reconstructed SST v4 from 1854 to 2018.

The agriculture sector, in particular, is sensitive to the large interannual variability in precipitation requiring careful management of surface and soil water [14]. In winter and spring, extratropical cyclones are the only source of precipitation for the Canadian Prairies due to its distance from the Pacific Ocean and its location on the westward (leeward) side of the Rocky Mountains. Winter snowfall and subsequent spring melt supply soil moisture for the production of crops. With recent climate change, the storm tracks exhibit an overall poleward shift according to the analysis of observational data and climate model output in northern high latitudes [15-17]. Reference [18] showed, however, that elevated tropical Pacific sea surface temperatures cause a southward shift of the storm track over North America. Previous investigations reveal a strong regional and seasonal dependence of storm activity and extreme weather events [15].

The Prairie region of Canada experiences both severe drought and extreme precipitation. The coefficient of variation of the climate moisture index in Canada is highest over the Prairies and southern interior British Columbia [19-21]. Previous studies [22-24] have investigated the atmospheric, hydrological, and land surface processes associated with extreme hydroclimatic events such as severe droughts and floods. While various studies [5], reference [25-27] have examined the recorded Prairie weather associated with ENSO, but the linkages between El Niño/La Niña and hydrological parameters have not been simulated for the extreme phases of ENSO. The relatively scarce distribution of weather stations suggests a model-based detailed spatial analysis of climatological and hydrological parameters during ENSO events. So, in this study, we investigate the teleconnections between the strong El Niño in 2015-2016 and strong La Niña in 2010-2011 and hydrometeorological parameters in the Canadian Prairies using high-resolution output from the Weather Research and Forecasting Model (WRF). This study compares the two extreme hydrological scenarios in the Prairies in the context of ENSO teleconnection in the last decades.

\section{Methodology and Modeling Experiment}

The National Center for Atmospheric Research (NCAR) Weather Research and Forecasting (WRF) model version 4.0 [28] is a mesoscale numerical weather prediction system suitable for atmospheric research and operational forecasting with a resolution of thousands of kilometers to a few meters. 
The WRF model offers a wide choice of physics and dynamical packages along with different parameterization options, which makes it widely used for regional climate studies.

In this study, the WRF model was configured with a nested domain (two-way nesting but feedback option turned off in the namelist) and a horizontal grid resolution of $30 \mathrm{~km}$ and $10 \mathrm{~km}$. The higher-resolution domain primarily focuses on the Prairie provinces extending from the eastern slopes of the Canadian Rockies to western Ontario. The coarser resolution domain covers a much larger area, which includes almost the entire Canadian landmass and the northern part of the USA (Figure 2). The model parameterization includes WRF Single Moment class 6 (WSM6) microphysics [29], Kain Fritsch cumulus physics [30], Community Atmosphere Model (CAM) longwave and shortwave radiation [31], MYNN2 planetary boundary layer physics [32,33], Revised MM5 Monin-Obukhov Scheme surface clay physics [34], and unified NOAH Land Surface model surface physics [35]. The WRF simulated precipitation data were evaluated against the ANUSPLIN gridded observational dataset produced by Natural Resources Canada (NRCan), and available at $10 \mathrm{~km}$ resolution over Canada [36-38].

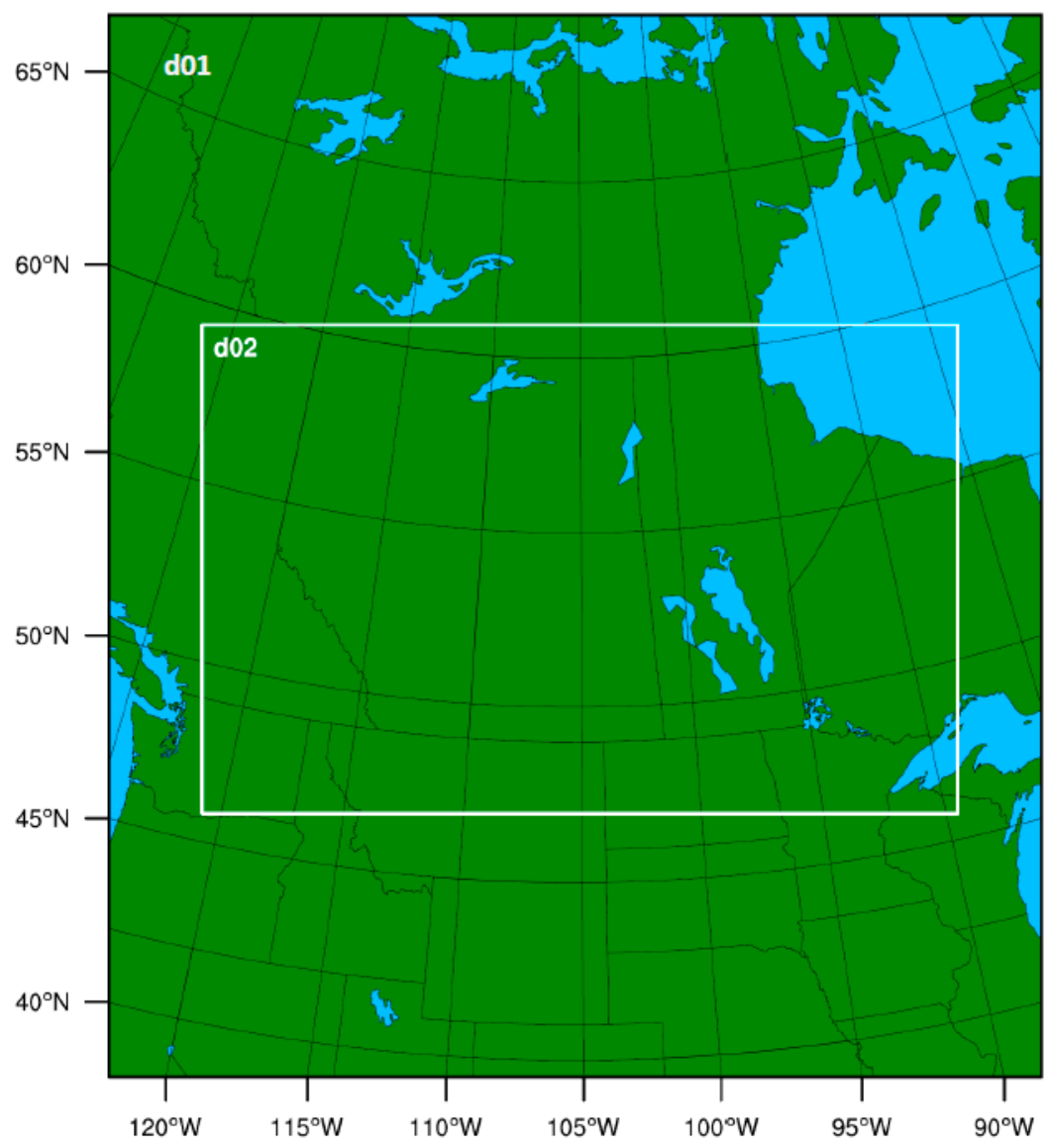

Figure 2. The mother domain $(\mathrm{d} 01)$ at $30 \mathrm{~km}$ resolution and the nested domain (d02) with $10 \mathrm{~km}$ resolution.

The high-resolution of the model output simulates spatial variation on a $10 \mathrm{~km}$ grid for hydroclimatic parameters such as snow depth, precipitation, surface runoff, and soil moisture, which is not captured in the observed data from weather stations located hundreds of kilometers apart. In the database of adjusted and homogenized weather data for Canada [39], there are only 97 weather stations in the Prairie provinces over an area of $\approx 1,780,650 \mathrm{~km}^{2}$, that is, one station for every $\approx 18,350 \mathrm{~km}^{2}$.

The justification for using WRF in this study was: (i) the absence of a dataset of observed values at a resolution finer than $50 \mathrm{~km}$, (ii) the unavailability of data for hydrometeorological parameters 
such as soil moisture, surface runoff, snow depth, et cetera, among the existing gridded datasets for the Prairie region, and (iii) dynamical downscaling using WRF can provide gridded precipitation data for the Prairies at $10 \mathrm{~km}$ resolution enabling us to investigate the regional distribution of the hydrometeorological parameters during the two hydrological extreme years in the last decade. In our La Niña (LAX) and El Niño (ELX) experiments, the WRF simulation was forced with 6 hourly European Centre for Medium-Range Weather Forecasts Reanalysis (ERA) interim surface and pressure level data for the modeling of years 2010-2011 and 2015-2016, respectively. The model simulations extended from 15 November to 31 May to allow $\approx 2$ weeks of model spin up time. However, the study uses the simulation results from 1 December to 31 May. The two seasons discussed in this paper were defined in a conventional way-winter (December-February) and spring (March-May). The modeling experiment produced hourly outputs of the hydrometeorological parameters such as precipitation, soil moisture, snow depth, and surface runoff.

\section{Results}

The cold climate hydrology of the Prairies is primarily dependent on winter and spring precipitation from mid-latitude storms. The Rocky Mountains receive the heaviest precipitation from these storm systems and this water is transported across the adjacent plains by major rivers. Figures 3 and 4 show the total precipitation $(\mathrm{mm})$ calculated from the model output of accumulated non-convective and convective precipitation for each winter and spring, respectively, for the La Niña of 2010-2011 and El Niño of 2015-2016. In the figures, the blue color indicates a higher amount of precipitation. In both seasons, the Rocky Mountains received maximum precipitation of 140-200 mm. However, a secondary precipitation maximum extends widely over Alberta and Saskatchewan in LAX. In spring 2016 the highest precipitation occurs over most of the Canadian Prairies (Figure 4) in both the experiments. The winter months for 2015-2016 received less precipitation than 2010-2011 (Figure 3).

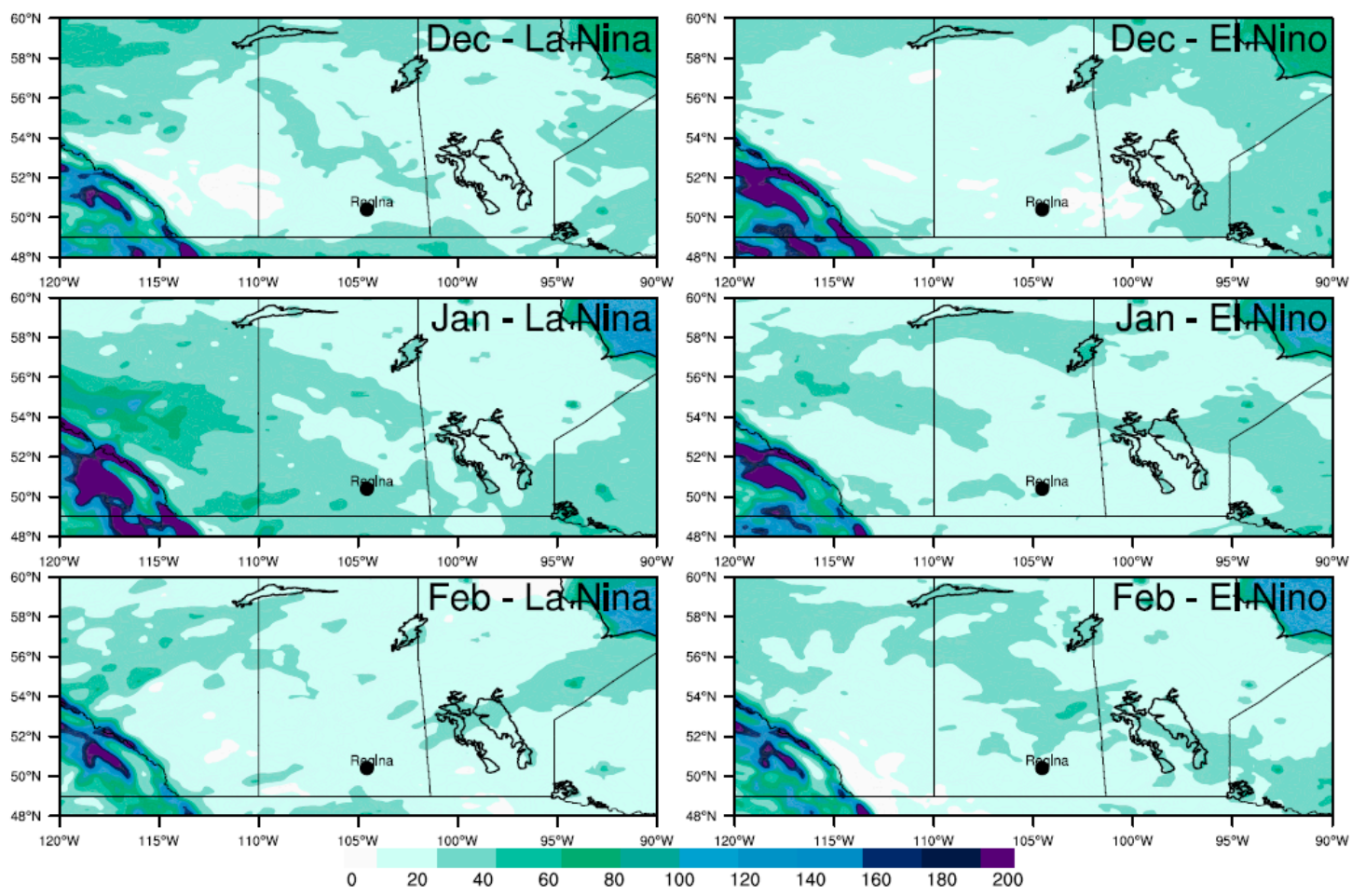

Figure 3. WRF simulated total precipitation ( $\mathrm{mm}$ ) for winter (December, January, and February) during the La Niña of 2010-2011 and El Niño of 2015-2016. 

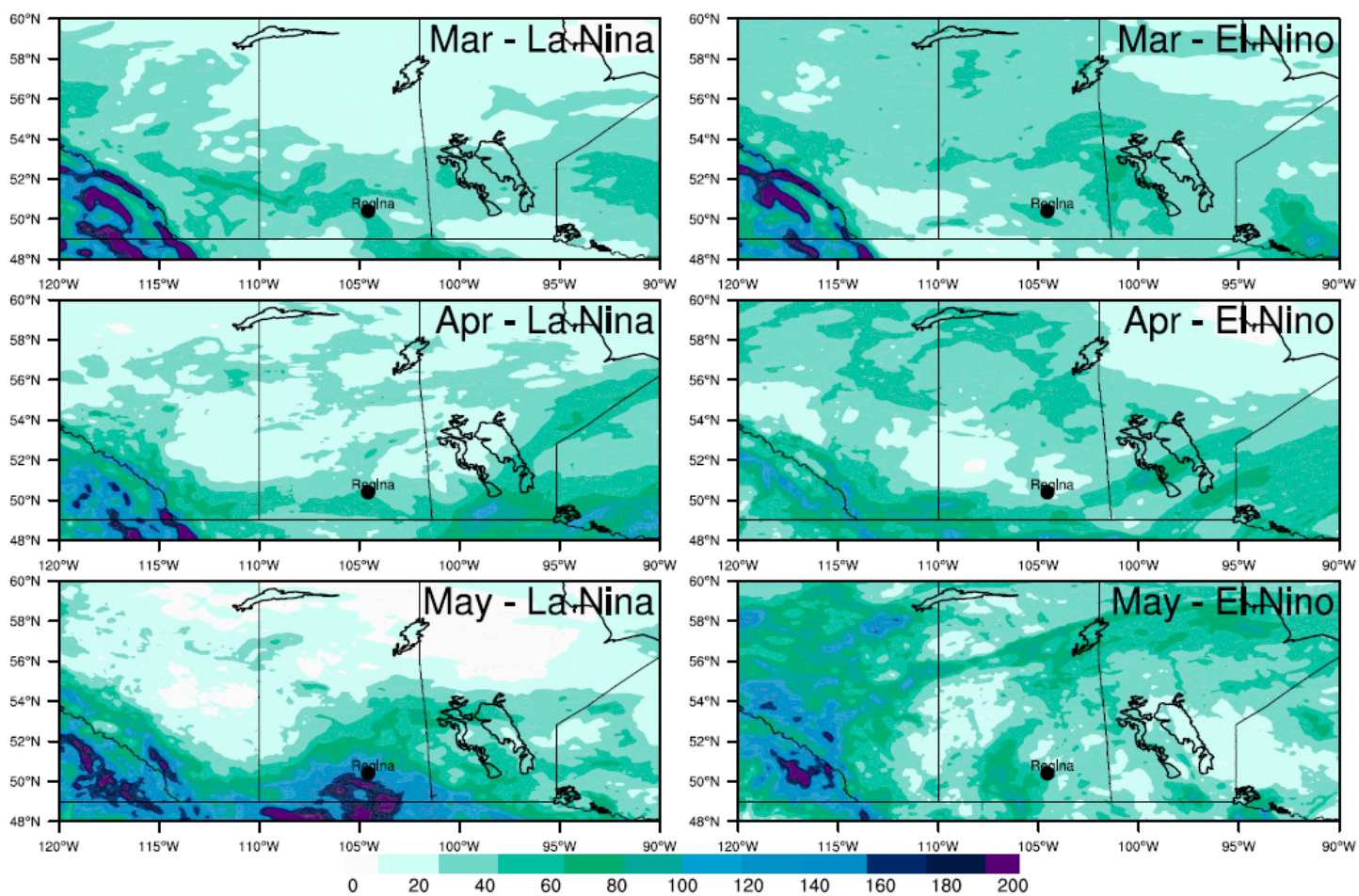

Figure 4. WRF simulated total precipitation $(\mathrm{mm})$ for spring (March, April, and May) during the La Niña of 2010-2011 and El Niño of 2015-2016.

A comparison (ELX-LAX) of the total winter and spring precipitation reveals a decrease in winter precipitation by 20 to $40 \mathrm{~mm}$ over the Canadian Prairies in 2015-2016 (Figure 5). During spring, the total precipitation increases over the northern part of the Prairie provinces but decreases over southern Saskatchewan in May. In both winter and spring, the Canadian Rockies exhibits the highest difference in total precipitation with remarkably lower precipitation in ELX.
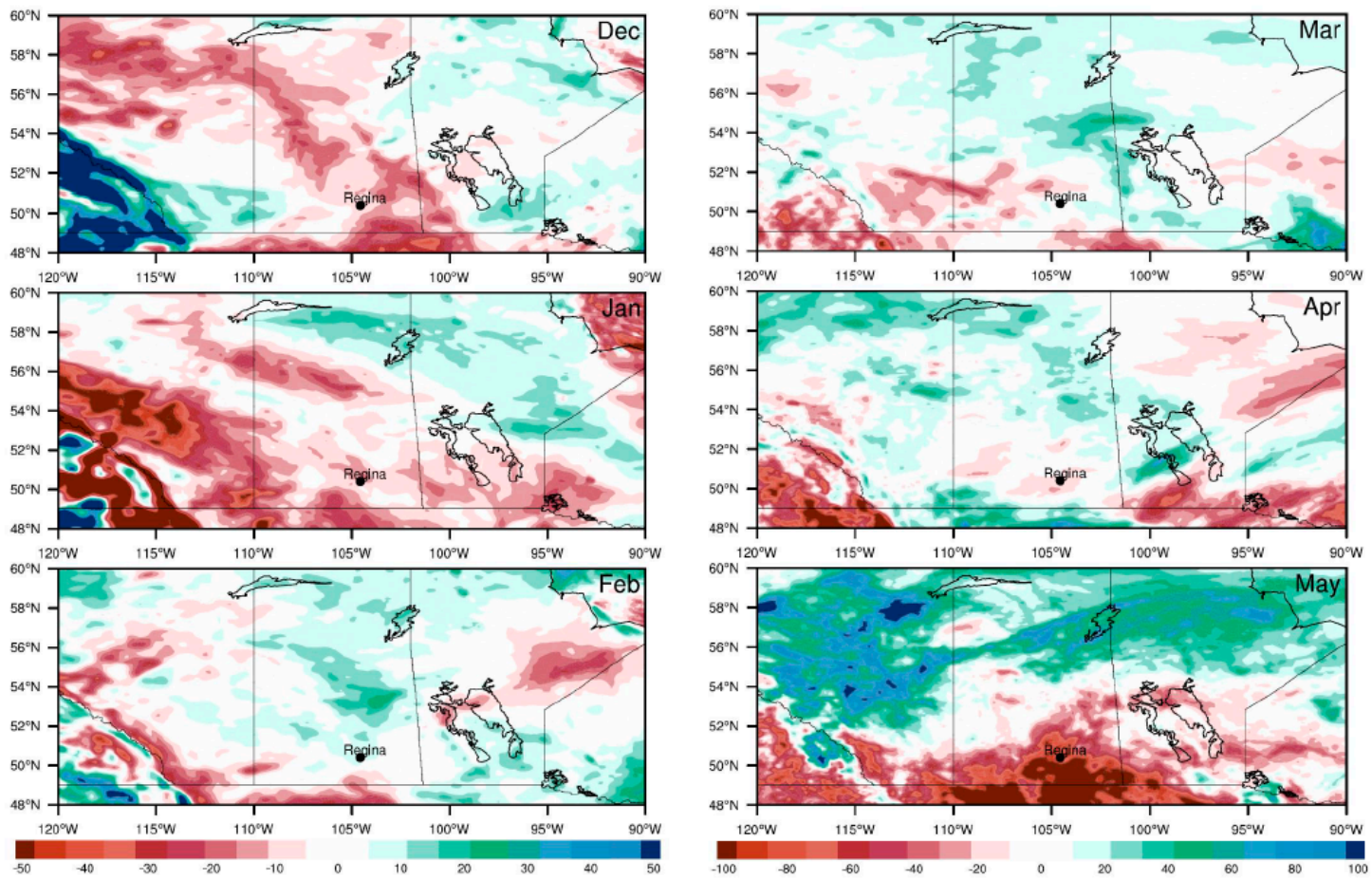

Figure 5. The difference (ELX-LAX) in WRF simulated total precipitation (mm) for winter and spring. 
The model simulated precipitation corresponds well with the historical observed precipitation. The model result shows similar changes in total precipitation with a decrease in winter precipitation over the Canadian Prairies and an increase in precipitation in spring precipitation over the northern region of Alberta, Saskatchewan, and Manitoba in 2015-2016 (Figure 6). Table 1 shows the quantitative assessment of the changes in precipitation.
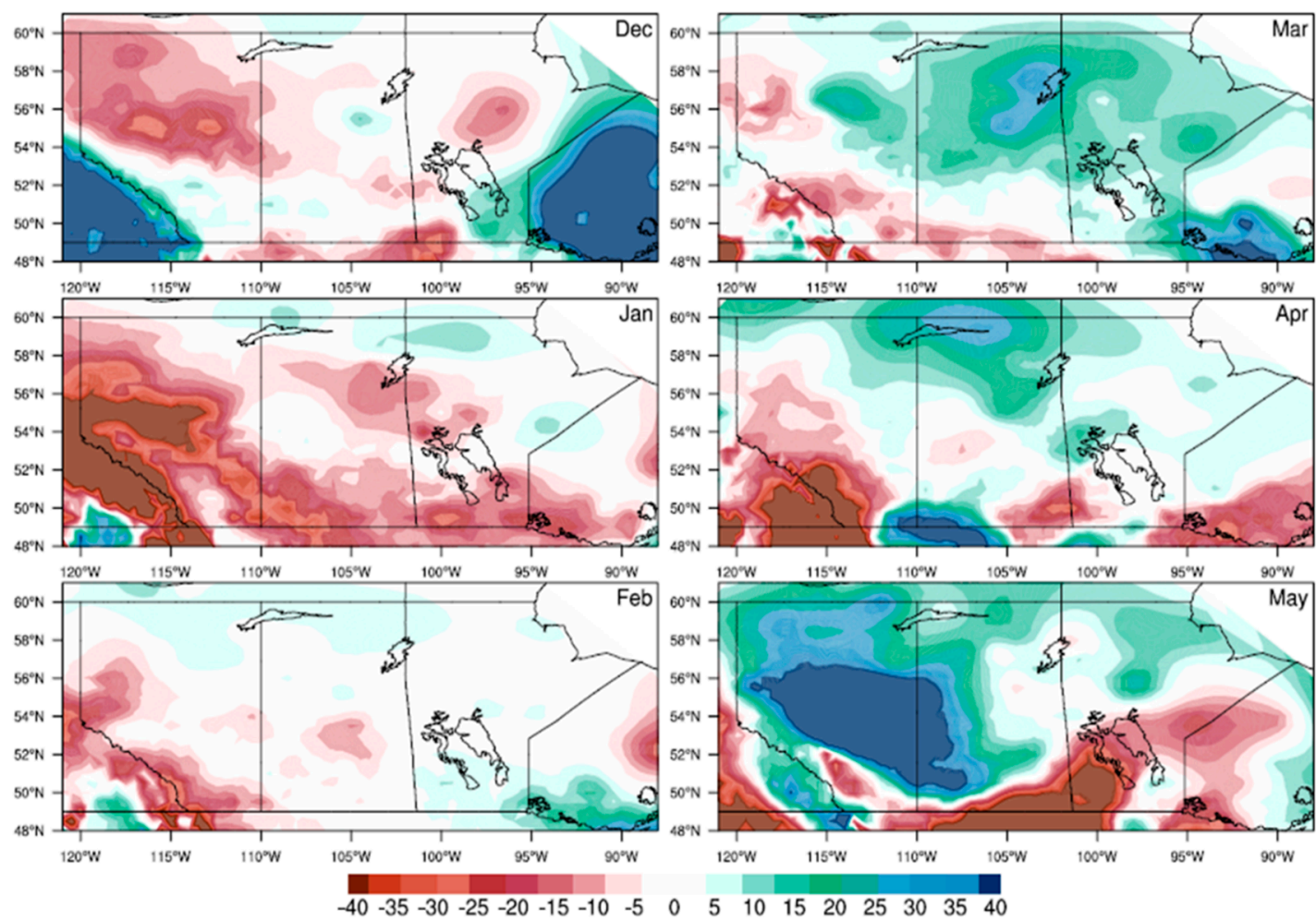

Figure 6. Gridded $10 \mathrm{~km}$ resolution observed (ANUSPLIN) total precipitation (mm) differences (2015-2016; 2010-2011) for December to May.

Table 1. Changes in precipitation $(\mathrm{mm})$ between La Niña and El Niño in simulation and observation in Regina.

\begin{tabular}{ccccc}
\hline & $\begin{array}{c}\text { Simulated } \\
\text { La Nina }\end{array}$ & $\begin{array}{c}\text { Simulated } \\
\text { El Nino }\end{array}$ & $\begin{array}{c}\text { Simulated } \\
\text { Difference }\end{array}$ & $\begin{array}{c}\text { Observed } \\
\text { Difference }\end{array}$ \\
\hline December & 24 & 19 & -5 & -1 \\
\hline January & 42 & 26 & -16 & -12 \\
\hline February & 21 & 27 & 6 & 2 \\
\hline March & 48 & 53 & 5 & 2 \\
\hline April & 52 & 41 & -11 & -16 \\
\hline May & 121 & 62 & -59 & -36 \\
\hline
\end{tabular}

The accumulated snow from winter precipitation plays a significant role in the regional energy and water balance. Typically, snow depth increases from late November through February before it starts melting in March. The map of snow depth in Figure 7 illustrates the dry winter of 2015-2016 in ELX. For example, in the city of Regina snow depth was 0-0.2 m with no snow cover in December. This pattern of extremely low snow depth persisted over the entire Canadian Prairies in the winter months in ELX. The highest snow accumulation occurs over the Rockies. The difference (ELX-LAX) of the snow depth simulations shows $20-40 \mathrm{~cm}$ less during the El Niño in comparison to the La Nina 
winter (Figure 8). The entire Canadian Prairies exhibits a prominent deficit in snow depth in the winter months of 2015-2016.

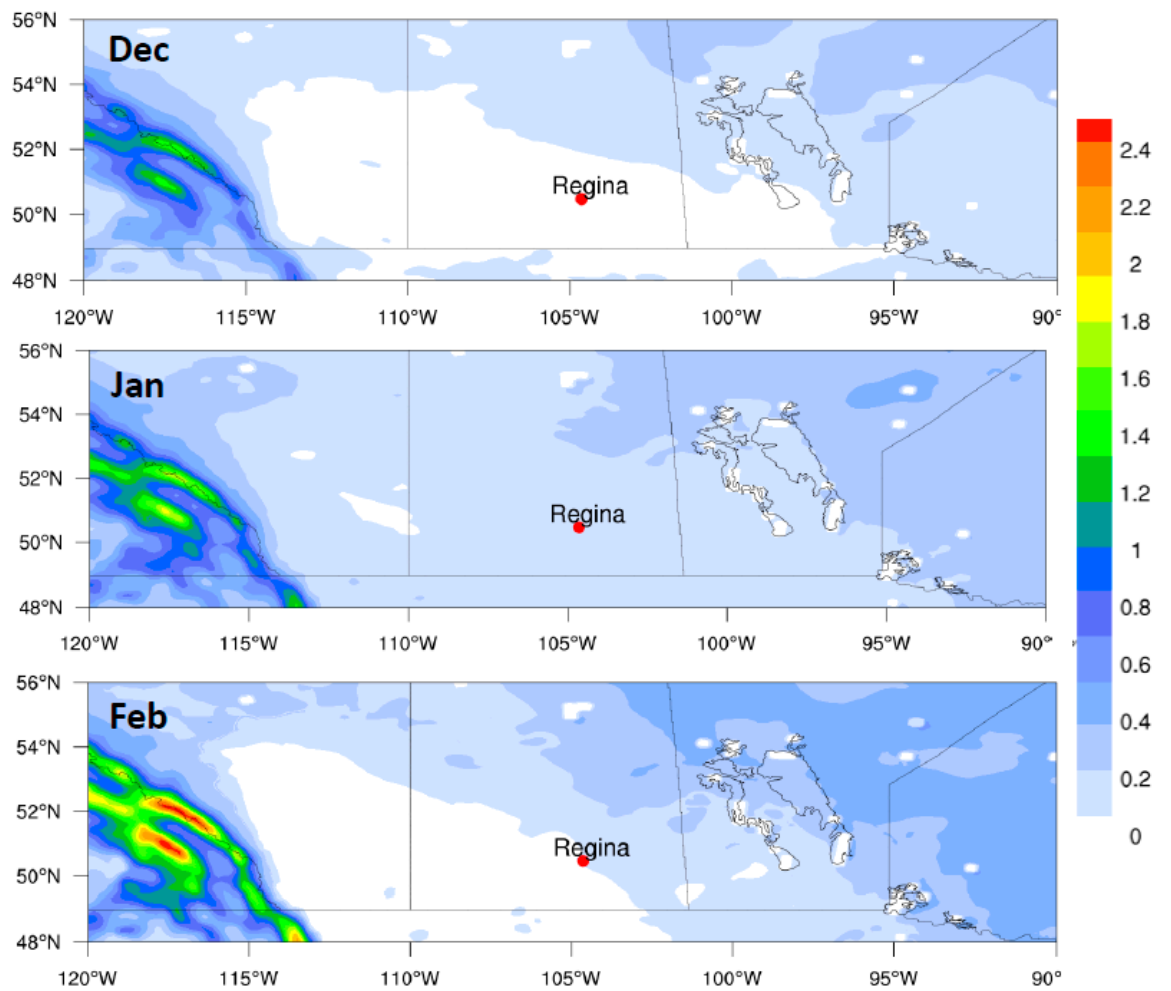

Figure 7. WRF simulated snow depth (m) in the winter of 2015-2016 in ELX experiment.

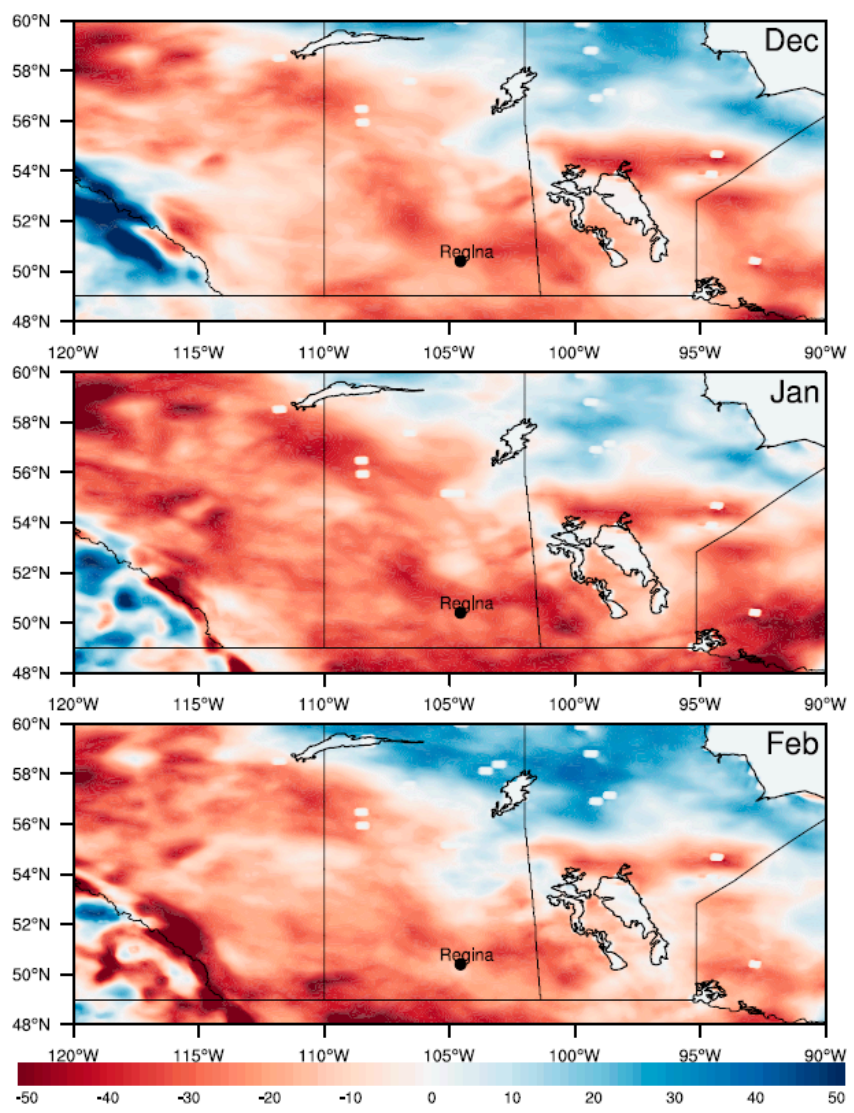

Figure 8. WRF simulated difference (ELX-LAX) in snow depth $(\mathrm{cm})$ for winter. 
In Canada's western interior, spring snowmelt runoff recharges soil moisture and the levels of lakes and rivers. Figure 9 shows the difference in the spring runoff between the ELX and LAX. In the ELX, due to a drier and warmer winter, the surface runoff in spring was reduced by 100-200 $\mathrm{mm}$ in May over the southern Prairies. Surface runoff increases in the ELX over the northern parts of the Prairie provinces, and high elevations of the Rocky Mountains, but otherwise is reduced prominently.
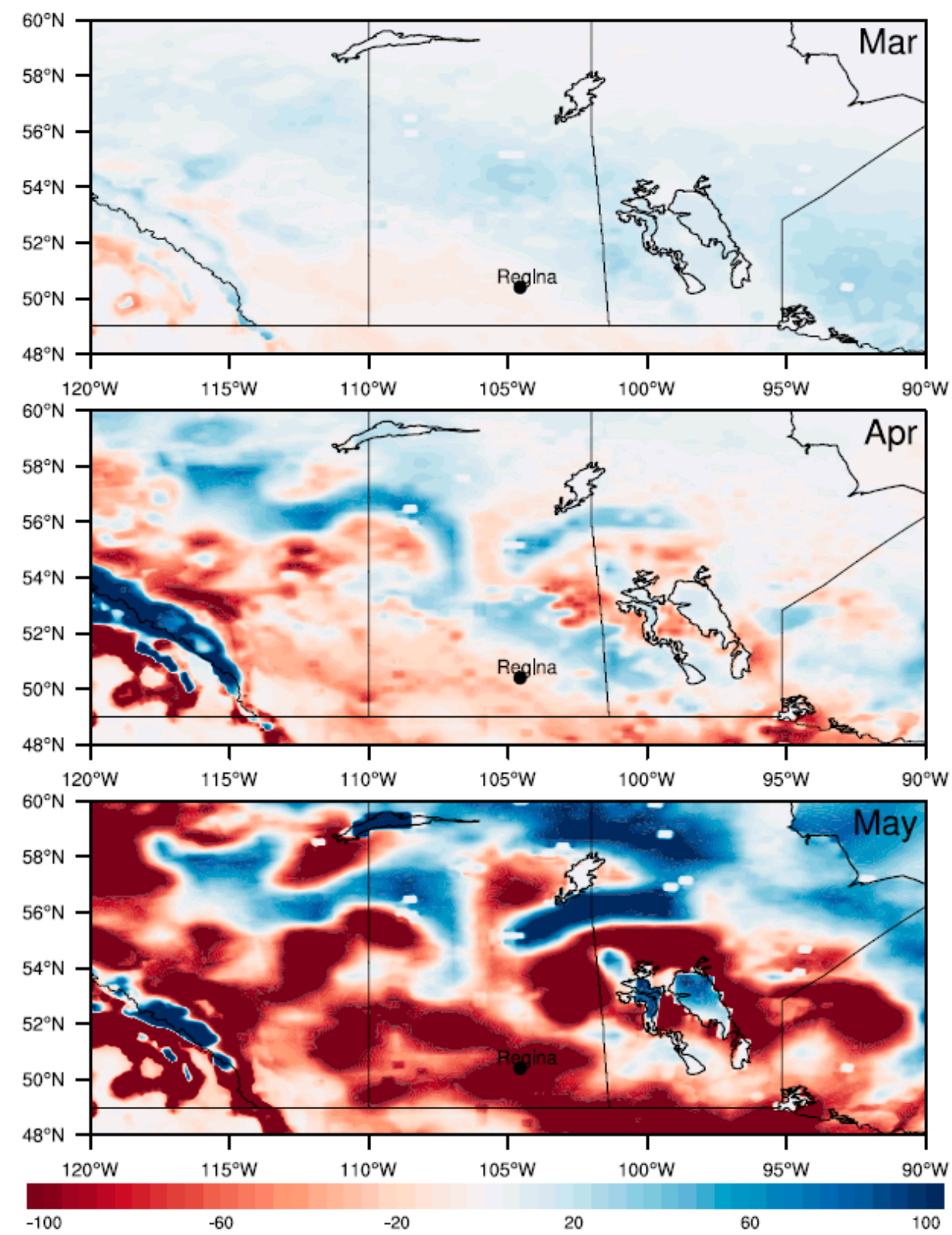

Figure 9. WRF simulated difference (ELX-LAX) in spring runoff (mm).

Streamflow is an indirect measure of surface runoff. The simulated surface runoff from the WRF experiments corresponds well with the observed streamflow at various sites in the Saskatchewan River Basin in Alberta and Saskatchewan. Table 2 records the changes in Saskatchewan River Basin streamflow from the Water Survey of Canada (WSC) which shows a prominent decrease in the river discharge in the Canadian Prairies during spring 2016 in comparison to spring 2011. 
Table 2. Differences in recorded flow $\left(\mathrm{m}^{3} / \mathrm{s}\right)$ of the North and South Saskatchewan Rivers (NSR and SSR) in Alberta (AB) and Saskatchewan (SK) between 2011 and 2016.

\begin{tabular}{cccc}
\hline \multirow{2}{*}{ STREAMFLOW GAUGE } & \multicolumn{3}{c}{ Difference $\left(\mathbf{m}^{3} / \mathbf{s} ; \mathbf{2 0 1 6}-\mathbf{2 0 1 1}\right)$} \\
\cline { 2 - 4 } & March & April & May \\
\hline NSR near Deer Creek, AB & 101 & -31 & -216 \\
\hline NSR at Prince Albert, SK & 83 & -138 & -290 \\
\hline SSR at Medicine Hat, AB & -28.9 & -207.7 & -484 \\
\hline SSR at Saskatoon, SK & -121 & -168 & -676.8 \\
\hline
\end{tabular}

The recharge of soil moisture from the melting spring snowpack is critical for the production of crops in the Prairies. A comparison of the spring soil moisture $\left(\mathrm{m}^{3} \mathrm{~m}^{-3}\right)$ between ELX and LAX indicates notably reduced soil moisture over the southern prairies starting in March and continuing until May (Figure 10). A secondary prominent decrease in soil moisture occurs over the northern part of the Prairie provinces in April-May.

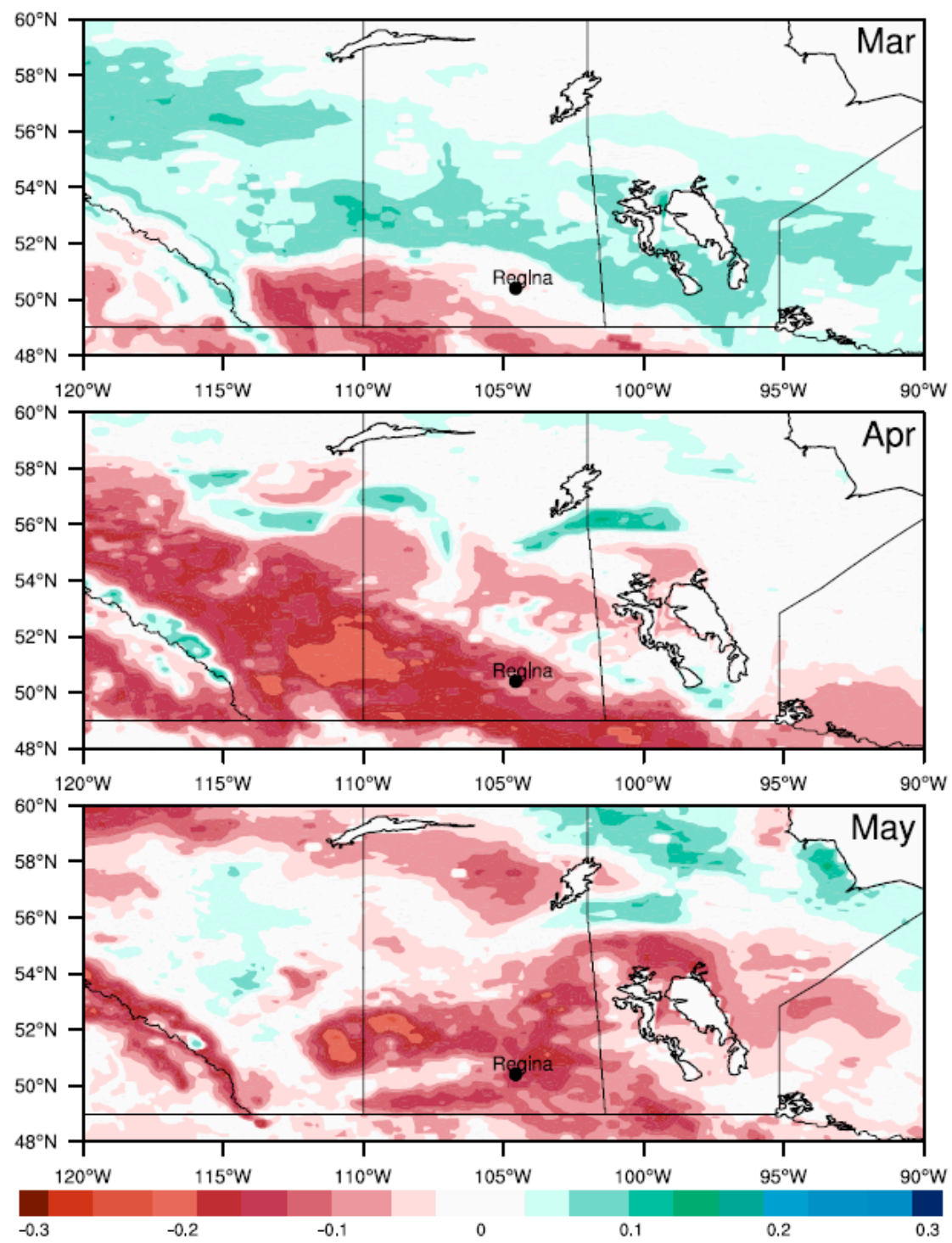

Figure 10. WRF simulated difference (ELX-LAX) in spring soil moisture $\left(\mathrm{m}^{3} \mathrm{~m}^{-3}\right)$. 
The decrease in soil moisture simulated in the modeling experiments is consistent with data provided by Alberta Agriculture and Forestry, Alberta Climate Information Service (ACIS) https: //agriculture.alberta.ca/acis. The soil moisture data are recorded at weather stations outfitted with soil moisture sensors at three depths (Theta Probe ML2X from Delta-T Device Ltd., Cambridge, UK). Table 3 shows the changes in soil moisture (first $5 \mathrm{~cm}$ ) in volume $\%$ and precipitation changes in $\mathrm{mm}$ for several stations in the Alberta network. The recorded soil moisture shows a consistent decrease in spring 2016. Thus, the observed changes in total precipitation (Figure 6) and soil moisture (Table 3) correspond well with the spatial changes obtained from the WRF simulations (Figures 5 and 9).

Table 3. Difference between 2016 and 2011 of observed soil moisture (first $5 \mathrm{~cm}$ ) in volume \% in Alberta (AB).

\begin{tabular}{cccccc}
\hline & \multicolumn{3}{c}{ Difference $\mathbf{~ ( m ~}^{\mathbf{3}} \mathbf{~ m}^{-\mathbf{3}}$; 2016-2011) } \\
\cline { 2 - 5 } Drought Net Stations & \multicolumn{3}{c}{ SOIL MOISTURE } & \multicolumn{2}{c}{ PRECIPITATION } \\
\cline { 2 - 5 } (AGDM) & March & April & May & WINTER & SPRING \\
\cline { 2 - 5 } & -0.029 & 6.239 & -6.394 & -29.4 & 62.7 \\
Manning (North, AB) & 9.191 & -7.555 & -3.16 & -11.24 & 59.1 \\
Stettler (South Central, AB) & 12.705 & -11.347 & -10.98 & -1.4 & -78.7 \\
Neir (South West, AB) & -0.547 & -9.48 & -5.397 & -18.9 & -12.4 \\
Del Bonita (South, AB) & 8.005 & -4.121 & -0.006 & -14.3 & 123 \\
Mundare (Central, AB) & & & & & \\
\hline
\end{tabular}

The changes in various hydroclimatic parameters indicate a strong relationship with the ENSO teleconnection pattern and the Prairie region hydrology. A detailed simulation across the Prairie region, during the El Niño of spring 2015-2016, exhibits a decrease in total precipitation in winter and hence a lesser snow accumulation leading to a decrease in surface runoff and soil moisture. The modeling result corresponds well with the previous research showing that southwestern Canada receives less precipitation in winter-spring in El Niño years, whereas north-central Canada has surplus precipitation due to a split jet stream [27] and a southward shift in the winter and spring extratropical cyclone tracks during El Niño event [18]. Previous research [40] showed two spatially well defined Prairie regions associated with the temporal evolution of droughts due to ENSO teleconnection using ANUSPLIN data whereas in this study we showed the spatial variability of the hydroclimate parameters due to two extreme phases of ENSO by a dynamical downscaling method using high-resolution WRF simulations.

\section{Conclusions}

El Niño and La Niña conditions in the Tropical Pacific affect the weather of Canadian Prairies through shifts in atmospheric circulation. A southward shift and splitting of the jet stream result in a southward shift of the North Pacific and North American storm track. As a result, the mid-latitude region gets fewer extratropical cyclones during El Niño events. A strong teleconnection between the two phases of ENSO and the mid-latitude climate produces prominent interannual variability of hydroclimate parameters, especially precipitation, in the Canadian Prairies. In the last decade, strong El Niño and La Niña events occurred in 2015-2016 and 2010-2011, respectively. In our modeling experiment, the WRF model was implemented with 6 hourly ERA interim surface and pressure level data as the lateral boundary conditions over the study domain for these El Niño and the La Niña years.

The main findings of this study are as follows:

(1) A lesser amount of precipitation in winter and spring during the El Niño of 2015-2016 in comparison to the 2010-2011 La Niña.

(2) A decrease in soil moisture and surface runoff during the El Niño event of 2015-2016, especially in the southern Prairies. 
(3) The model simulation of precipitation, snow depth, and runoff during the El Niño of 2015-2016 and La Nina of 2010-2011 corresponds with observational data from weather stations and water gauges.

The variability in precipitation associated with ENSO has significant implications for the Canadian Prairies, the large region defined by a negative annual average water balance, and which accounts for more than $80 \%$ of the nation's agricultural land. Recent climate change projections $[3,13]$ for western Canada suggest increased precipitation and inter-annual variation as a consequence of global warming. Previous research on the historical and projected hydroclimate of western Canada [1,2,6-8,13,27,40,41] demonstrated the sensitivity of the surface and groundwater hydrology to climate change trends and to inter-annual to decadal scale variability related to teleconnections with large-scale climate patterns. The extent of these changes differs among climate models and greenhouse gas emission scenarios; however, the largest course of uncertainty is the internal variability of the regional climate regime [3]. Much of this natural variability is linked to ENSO as demonstrated here for two strong and recent ENSO events. The capacity of the WRF model to simulate the consequences of ENSO for the soil and surface hydrology enables us to capture these effects with a high spatial and temporal resolution, and model the teleconnection between ENSO and regional hydroclimate as the climate continues to warm. However, this study is limited to a comparison between two hydrological extreme years in the last decade. A generalization and projection of the knowledge acquired from this study to future events would require an extensive study of the historical ENSO events.

Author Contributions: S.B. and D.J.S. planned the experiments. S.B. conducted the modeling experiments, performed the analysis, and prepared the text and graphics for the manuscript. D.J.S. contributed to writing the manuscript and overall supervision of the project. M.R.A. conducted the analysis of the observed streamflow and the soil moisture and prepared Tables 2 and 3. All authors have read and agreed to the published version of the manuscript.

Funding: This research was funded by Natural Sciences and Engineering Research Council of Canada (NSERC) (Grant \# 1454/2013). Queen Elizabeth II Advanced Scholar (QES) program provided funding support for Soumik Basu. QES program was funded by IDRC and SSHRC.

Acknowledgments: We would like to thank the Queen Elizabeth II Advanced Scholar (QES) program for financial support. The QES program is made possible with funding from IDRC and SSHRC. We also thank the Natural Sciences and Engineering Research Council of Canada who also provided funding (Grant \# 1454/2013). We thank Westgrid (https://www.westgrid.ca/) and Compute Canada (www.computecanada.ca) for computational support. The model forcing data can be retrieved online (at https://rda.ucar.edu/datasets/ds627.0/); the CMIP5 data can be retrieved online (at https://esgf-node.llnl.gov/projects/cmip5/) and the CORDEX data can be retrieved online (at https://na-cordex.org/).

Conflicts of Interest: The authors declare no conflict of interest.

\section{References}

1. Sauchyn, D.; Vanstone, J.; Perez-Valdivia, C. Modes and Forcing of Hydroclimatic Variability in the Upper North Saskatchewan River Basin Since 1063. Can. Water Resour. J./Rev. Can. Ressour. Hydr. 2011, 36, 205-217. [CrossRef]

2. Jacques, J.-M.S.; Huang, Y.A.; Zhao, Y.; Lapp, S.L.; Sauchyn, D.J. Detection and attribution of variability and trends in streamflow records from the Canadian Prairie Provinces. Can. Water Resour. J. Rev. Can. Ressour. Hydr. 2014, 39, 270-284. [CrossRef]

3. Barrow, E.M.; Sauchyn, D.J. Uncertainty in climate projections and time of emergence of climate signals in the western Canadian Prairies. Int. J. Clim. 2019, 39, 4358-4371. [CrossRef]

4. Stewart, R.E.; Szeto, K.K.; Bonsal, B.R.; Hanesiak, J.M.; Kochtubajda, B.; Li, Y.; Thériault, J.M.; Debeer, C.M.; Tam, B.Y.; Li, Z.; et al. Summary and synthesis of Changing Cold Regions Network (CCRN) research in the interior of western Canada-Part 1: Projected climate and meteorology. Hydrol. Earth Syst. Sci. 2019, 23, 3437-3455. [CrossRef]

5. Bonsal, B.R.; Zhang, X.; Vincent, L.A.; Hogg, W.D. Characteristics of Daily and Extreme Temperatures over Canada. J. Clim. 2001, 14, 1959-1976. [CrossRef] 
6. Bonsal, B.; Shabbar, A. Impacts of Large-Scale Circulation Variability on Low Streamflows over Canada: A Review. Can. Water Resour. J./Rev. Can. Ressour. Hydr. 2008, 33, 137-154. [CrossRef]

7. Szeto, K.; Zhang, X.; White, R.E.; Brimelow, J. The 2015 Extreme Drought in Western Canada. Bull. Am. Meteorol. Soc. 2016, 97, S42-S46. [CrossRef]

8. Li, Z.; Li, Y.; Bonsal, B.; Manson, A.H.; Scaff, L. Combined impacts of ENSO and MJO on the 2015 growing season drought on the Canadian Prairies. Hydrol. Earth Syst. Sci. 2018, 22, 5057-5067. [CrossRef]

9. Trenberth, K.E.; Hurrell, J.W. Decadal atmosphere-ocean variations in the Pacific. Clim. Dyn. 1994, 9, 303-319. [CrossRef]

10. Hoerling, M.P.; Ting, M. Organization of Extratropical Transients during El Niño. J. Clim. 1994, 7, 745-766. [CrossRef]

11. Eichler, T.; Higgins, W. Climatology and ENSO-Related Variability of North American Extratropical Cyclone Activity. J. Clim. 2006, 19, 2076-2093. [CrossRef]

12. Compo, G.; Sardeshmukh, P.D. Removing ENSO-Related Variations from the Climate Record. J. Clim. 2010, 23, 1957-1978. [CrossRef]

13. Bonsal, B.; Cuell, C.; Wheaton, E.; Sauchyn, D.J.; Barrow, E. An assessment of historical and projected future hydro-climatic variability and extremes over southern watersheds in the Canadian Prairies. Int. J. Clim. 2017, 37, 3934-3948. [CrossRef]

14. Corkal, D.; Diaz, H.; Sauchyn, D. Changing Roles in Canadian Water Management: A Case Study of Agriculture and Water in Canada's South Saskatchewan River Basin. Int. J. Water Res. Dev. 2011, 27, 647-664.

15. Zhang, X.; Walsh, J.E.; Zhang, J.; Bhatt, U.S.; Ikeda, M. Climatology and Interannual Variability of Arctic Cyclone Activity: 1948-2002. J. Clim. 2004, 17, 2300-2317. [CrossRef]

16. Yin, J.H. A consistent poleward shift of the storm tracks in simulations of 21st century climate. Geophys. Res. Lett. 2005, 32. [CrossRef]

17. Ulbrich, U.; Leckebusch, G.C.; Pinto, J.G. Extra-tropical cyclones in the present and future climate: A review. Theor. Appl. Clim. 2009, 96, 117-131. [CrossRef]

18. Basu, S.; Zhang, X.; Polyakov, I.; Bhatt, U.S. North American winter-spring storms: Modeling investigation on tropical Pacific sea surface temperature impacts. Geophys. Res. Lett. 2013, 40, 5228-5233. [CrossRef]

19. Environment and Climate Change Canada. Standardized Precipitation Evapotranspiration Index Data. 2019. Available online: http://climate-scenarios.canada.ca/?page=spei (accessed on 23 September 2019).

20. Bush, E.; Lemmen, D.S. (Eds.) Canada's Changing Climate Report; Government of Canada: Ottawa, ON, Canada, 2019; 444p.

21. Hogg, E.H. Temporal scaling of moisture and the forest-grassland boundary in western Canada. Agric. For. Meteorol. 1997, 84, 115-122. [CrossRef]

22. Stewart, R.E.; Pomeroy, J.; Lawford, R. The Drought Research Initiative: A Comprehensive Examination of Drought over the Canadian Prairies. Atmosphere-Ocean 2011, 49, 298-302. [CrossRef]

23. Hanesiak, J.; Stewart, R.E.; Bonsal, B.R.; Harder, P.; Lawford, R.; Aider, R.; Amiro, B.D.; Atallah, E.; Barr, A.G.; Black, T.A.; et al. Characterization and Summary of the 1999-2005 Canadian Prairie Drought. Atmosphere-Ocean 2011, 49, 421-452. [CrossRef]

24. Pomeroy, J.; Stewart, R.E.; Whitfield, P.H. The 2013 flood event in the South Saskatchewan and Elk River basins: Causes, assessment and damages. Can. Water Resour. J. Rev. Can. Ressour. Hydr. 2015, 41, 105-117. [CrossRef]

25. Shabbar, A.; Yu, B. Intraseasonal Canadian Winter Temperature Responses to Interannual and Interdecadal Pacific SST Modulations. Atmosphere-Ocean 2012, 50, 109-121. [CrossRef]

26. Shabbar, A.; Khandekar, M. The impact of el Nino-Southern oscillation on the temperature field over Canada: Research note. Atmosphere-Ocean 1996, 34, 401-416. [CrossRef]

27. Shabbar, A.; Bonsal, B.; Khandekar, M. Canadian Precipitation Patterns Associated with the Southern Oscillation. J. Clim. 1997, 10, 3016-3027. [CrossRef]

28. Skamarock, W.C.; Klemp, J.B.; Dudhia, J.; Gill, D.O.; Liu, Z.; Berner, J.; Wang, W.; Powers, J.G.; Duda, M.G.; Barker, D.M.; et al. A Description of the Advanced Research WRF Version 4; No. NCAR/TN-556+STR; NCAR Tech: Boulder, CO, USA, 2019; 145p. [CrossRef]

29. Hong, S.-Y.; Lim, J.-O.J. The WRF single-moment 6-class microphysics scheme (WSM6). J. Korean Meteorol. Soc. 2006, 42, 129-151.

30. Kain, J.S. The Kain-Fritsch convective parameterization: An update. J. App. Met. 2004, 43, 170-181. [CrossRef] 
31. Collins, W.D.; Rasch, P.J.; Boville, B.A.; Hack, J.J.; McCaa, J.R.; Williamson, D.L.; Briegleb, B.P.; Bitz, C.M.; Lin, S.-J.; Zhang, M. The Formulation and Atmospheric Simulation of the Community Atmosphere Model Version 3 (CAM3). J. Clim. 2006, 19, 2144-2161. [CrossRef]

32. Nakanishi, M.; Niino, H. Development of an Improved Turbulence Closure Model for the Atmospheric Boundary Layer. J. Meteorol. Soc. Jpn. 2009, 87, 895-912. [CrossRef]

33. Olson, J.B.; Kenyon, J.S.; Angevine, W.M.; Brown, J.M.; Pagowski, M.; Sušelj, K. A Description of the MYNN-EDMF Scheme and the Coupling to Other Components in WRF-ARW; NOAA Technical Memorandum OAR GSD; NOAA: Washington, DC, USA, 2019; Volume 61, p. 37. [CrossRef]

34. Jiménez, P.A.; Dudhia, J.; González-Rouco, J.F.; Navarro, J.; Montávez, J.P.; García-Bustamante, E. A Revised Scheme for the WRF Surface Layer Formulation. Mon. Weather Rev. 2012, 140, 898-918. [CrossRef]

35. Tewari, M.; Chen, F.; Wang, W.; Dudhia, J.; LeMone, M.A.; Mitchell, K.; Ek, M.; Gayno, G.; Wegiel, J.; Cuenca, R.H. Implementation and verification of the unified NOAH land surface model in the WRF model. In Proceedings of the 20th Conference on Weather Analysis and Forecasting/16th Conference on Numerical Weather Prediction, Seattle, WA, USA, 12 January 2004; pp. 11-15.

36. Hutchinson, M.F.; McKenney, D.W.; Lawrence, K.; Pedlar, J.H.; Hopkinson, R.F.; Milewska, E.; Papadopol, P. Development and Testing of Canada-Wide Interpolated Spatial Models of Daily Minimum-Maximum Temperature and Precipitation for 1961-2003. J. Appl. Meteorol. Clim. 2009, 48, 725-741. [CrossRef]

37. Hopkinson, R.F.; McKenney, D.W.; Milewska, E.; Hutchinson, M.F.; Papadopol, P.; Vincent, L.A. Impact of Aligning Climatological Day on Gridding Daily Maximum-Minimum Temperature and Precipitation over Canada. J. Appl. Meteorol. Clim. 2011, 50, 1654-1665. [CrossRef]

38. McKenney, D.W.; Hutchinson, M.F.; Papadopol, P.; Lawrence, K.; Pedlar, J.; Campbell, K.; Milewska, E.; Hopkinson, R.F.; Price, D.; Owen, T. Customized Spatial Climate Models for North America. Bull. Am. Meteorol. Soc. 2011, 92, 1611-1622. [CrossRef]

39. Vincent, L.A.; Wang, X.L.; Milewska, E.J.; Wan, H.; Yang, F.; Swail, V. A second generation of homogenized Canadian monthly surface air temperature for climate trend analysis. J. Geophys. Res. Space Phys. 2012, 117. [CrossRef]

40. Asong, Z.E.; Wheater, H.S.; Bonsal, B.; Razavi, S.; Kurkute, S. Historical drought patterns over Canada and their teleconnections with large-scale climate signals. Hydrol. Earth Syst. Sci. 2018, 22, 3105-3124. [CrossRef]

41. Perez-Valdivia, C.; Sauchyn, D.; Vanstone, J. Groundwater levels and teleconnection patterns in the Canadian Prairies. Water Resour. Res. 2012, 48. [CrossRef]

Publisher's Note: MDPI stays neutral with regard to jurisdictional claims in published maps and institutional affiliations.

(C) 2020 by the authors. Licensee MDPI, Basel, Switzerland. This article is an open access article distributed under the terms and conditions of the Creative Commons Attribution (CC BY) license (http://creativecommons.org/licenses/by/4.0/). 